\title{
Otolith mass asymmetry in the mugilid fish, Liza klunzingeri (Day, 1888) collected from Persian Gulf near Bandar Abbas
}

\author{
Laith A. Jawad ${ }^{1} \&$ Zahra Sadighzadeh ${ }^{2}$ \\ 1 Manukau, Auckland, New Zealand. \\ 2 Marine Biology Department, Faculty of Marine Science \& Technology, Islamic Azad University, Hesarak, Tehran, Islamic, \\ Republic of Iran.
}

Correspondence
L. A. Jawad
E-mail: laith_jawad@hotmail.com
Received: 9 October 2013
Accepted: 28 november 2013
Published on-line: 17 December 2013

Correspondence

E-mail: laith_jawad@hotmail.com

Accepted: 28 november 2013

Published on-line: 17 December 2013

\begin{abstract}
Resumen
Asimetría de masa de los otolitos del mugílido Liza klunzingeri (Day, 1888), capturados en el Golfo Pérsico junto a Bandar Abbas
\end{abstract}

\begin{abstract}
Se calculó la asimetría de masa, $x$, como la diferencia entre la masa de otolidos pareados a izquierda y derecha, dividida por la masa media. Se estudió la asimetría del otolito sacular de Liza klunzingeri. Como en otras especies de peces simétricos, el valor absoluto de $x$ no dependió de la longitud del pez ni del ratio de crecimiento del otolito. El valor medio de $x$ estuvo entre $-0,2 y+0,2$.
\end{abstract}

Palabras clave: Otolito, Asimetría de masa, Mugilidae, Golfo Pérsico, Irán.

\begin{abstract}
The otolith mass asymmetry, $x$, was calculated as the difference between the mass of the right and left paired otoliths divided by average otolith mass. Saccular otolith mass asymmetry was studied in the mugilid fish Liza klunzingeri. As in the case of other symmetrical fish species, the absolute value of $x$ in L. klunzingeri does not depend on fish length and otolith growth rate. The mean value of $x$ was between -0.2 and +0.2 .
\end{abstract}

Key words: Otolith, Mass asymmetry, Mugilidae, Persian Gulf, Iran.

\section{Introduction}

Acoustic functionality of a fish can be altered by otolith asymmetry due to incompatibility and incongruity of the right and left otolith movement (Lychakov \& Rebane 2005, Lychakov et al. 2006). Such facts show that otolith mass asymmetry can have severe effects on vestibular and auditory functions, but the exact quantitative morphological and physiological bases of otolith asymmetry are still unclear (Lychakov et al. 2006).

Because of the nature of the fish otolith in being compacted, they were considered suitable as biological model for assessing quantitatively the physiological role of otolith mass asymmetry. The previous studies on otolith mass asymmetry showed that the majority of the fish species stu- died have this asymmetry within the range of $-0.2<x<+0.2$ or $<20 \%$ (Lychakov 1992, Lychakov et al. 1988, Lychakov \& Rebane 2004, 2005). In addition, the previous authors reach to a conclusion that there is no relationship between the magnitude of otolith mass asymmetry and length or mass of the fish. Such results could be attributed to the otolith mass fluctuation (Lychakov \& Rebane 2004, 2005). Moreover, researches on the otolith mass asymmetry in most symmetric fish species have shown that it is well below critical values, so they do not experienced functional impairment (Lychakov \& Rebane 2005, Lychakov et al. 2006). Taking the account that the mass of right and left paired otoliths are generally not equal (Lychakov 2002, Scherers 2001) it is clear that the otolith mass differences, or what 
known as mass asymmetry of otolith, could be one of the important factors that affect the quality of reception of fish acoustic environment.

The aim of the present study is two folds, first, to quantify and compare the value of the otolith mass asymmetry range, second, to asses the variability of this asymmetry during fish growth.

\section{Materials and Methods}

Data used in the present study were collected from 30 specimens of Liza klunzingeri collected on $3^{\text {rd }}$ July 2007 from Persian Gulf near Bandar Abbas. Standard length was measured following the procedure of Lychakov et al. (2006) prior to removal of otoliths. After the dissection of the auditory capsules, otoliths were removed from each side, rinsed in distilled water, air-dried at room temperature for few days, and then weighed on a Sartorius TE $313 \mathrm{~S}$ analytical balance to accuracy $0.0001 \mathrm{~g}$.

The otolith mass asymmetry $(x)$ was calculated from: $x=(\mathrm{MR}-\mathrm{ML}) \mathrm{M}^{-1}$, where MR and ML are the otolith masses of the right and left paired otoliths and $\mathrm{M}$ is the mean mass of the right and left paired otoliths.

In theory, $x$ value can vary between -2 and 2 , and $x=0$ represents the absence of mass asymmetry (MR $-\mathrm{ML}$ ), whereas $x=-2$ or $x=2$ represent the maximal asymmetry (absence of one otolith). The positive value of $x$ means that the right otolith mass is larger than the left paired otolith mass and a negative sign means the opposite.

The relation between species absolute value of $x$ and the species otolith growth rate was examined. The absolute value of the species otolith mass asymmetry is calculated as the average individual value.

\section{Results and Discussion}

The mean value of $\mathrm{x}$ is $0.1053 \pm 1.1436, \mathrm{n}=30$ (Fig. 1) and the mean value of IXI is $0.16667 \pm$ $0.0142, \mathrm{n}=52$ (Fig. 2). According to the regression analysis there was no relationship between fish length and both IXI $(\mathrm{y}=-0.0052 \mathrm{x}+0.1229)$ $\left(p>0.05, \mathrm{R}^{2}=0.0152\right)$ and $x(\mathrm{y}=-0.0038 \mathrm{x}+$ $0.0346)(p>0.05, \mathrm{R} 2=0.0049)$ (Figs. $1 \& 2)$.

The relation between otolith mass difference (MR - ML), and fish length was more complex than the relation between $\mathrm{x}$ and fish length $(\mathrm{n}=30$, total length $=121-178 \mathrm{~mm}, p>0.05, \mathrm{y}=-6 \mathrm{E}-05 x+$ 0.0006, $\mathrm{R}^{2}=0.0088$ ) (Fig. 3).

\section{Discussion}

As in other marine fish species (Lychakov et al 2008 ) the value of $x$ falls between -0.2 and +0.2 .

On the other hand the saccular otolith mass asymmetry was less than 0.05 a value that coincided with the value of mass asymmetry obtained for large number of marine species (Lychakov et al. 2006) and did not depend on otolith growth

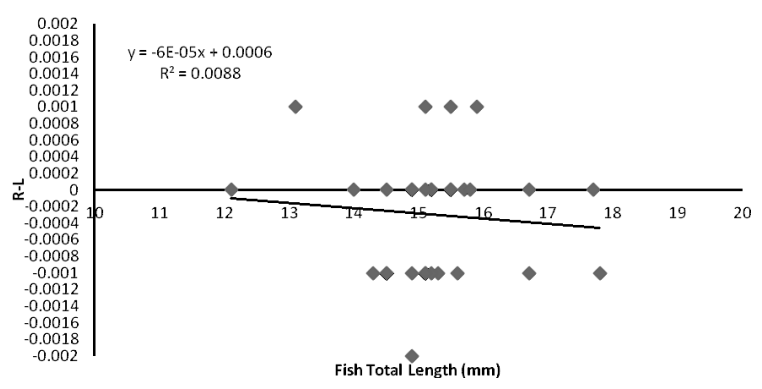

Figura 1. Asimetría de masa del otolito sacular en Liza klunzingeri, en función de la longitud del pez.

Figure 1. Saccular otolith mass asymmetry in Liza klunzingeri as a function of fish length.

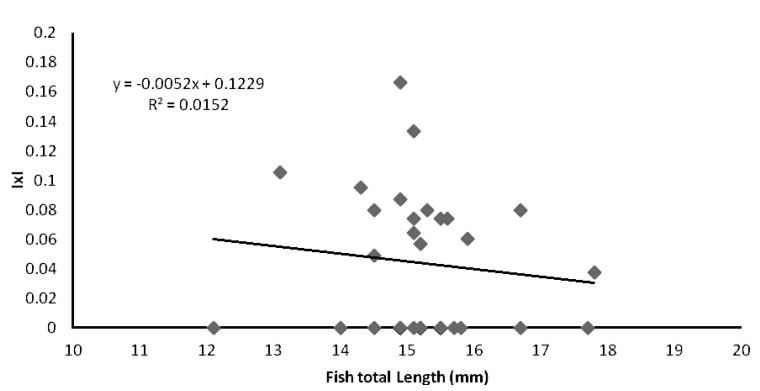

Figura 2. Asimetría de masa absoluta del otolito, en función de la longitud del pez en Liza klunzingeri.

Figure 2. Absolute otolith mass asymmetry as function of fish length in Liza klunzingeri.

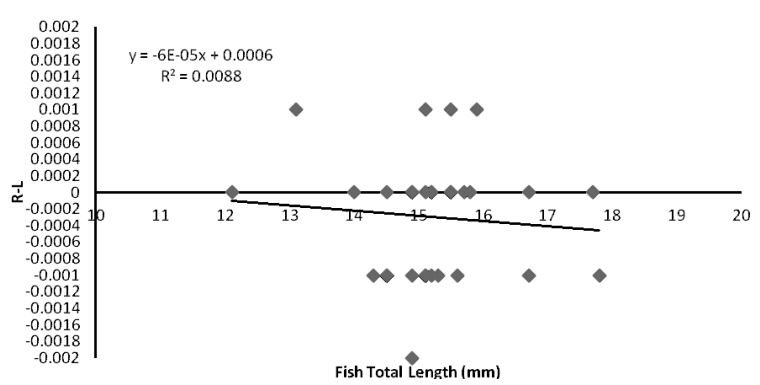

Figura 3. Diferencia de masa del otolito sacular en Liza klunzingeri, en función de la longitud del pez.

Figure 3. Saccular otolith mass difference in Liza klunzingeri as a function of fish length 
rate. The saccular otolith mass difference increases with the fish length and this is a characteristic of the littoral and bottom fishes and not the pelagic fishes (Lychakov \& Rebane 2004).

Lychakov \& Rebane $(2004,2005)$ have shown through the mathematical modelling they wrote that acoustic and vestibular functionality of a fish ear can be reduced due to otolith mass asymmetry. However, in the great majority of fishes studied (Lychakov et al. 2006), including the species in question, saccular otolith mass asymmetry is very low (IXI $=0.16667+0.0142)$, irrespective of fish length. This low level of otolith asymmetry is typical for utricular and lagenar otolith organs also in symmetric teleost fishes. On the other hand,

Lychakov \& Rebane (2005) have shown that only fishes that contain the largest otoliths and IXI $>0.2$ could, in theory, have difficulties with sound processing due to incompatibility and incongruity of the movement of the two otoliths on both sides of the head of the fish. Therefore, most fish species can avoid functional disability as they have otolith mass asymmetry below critical value.

The results obtained in the present work on saccular otolith mass asymmetry show it does not depend on fish size. This agrees with the results obtained by other workers on several marine and freshwater fish species (Lychakov \& Rebane 2004, 2005, Lychakov et al. 2006, Jawad et al., 2010). According to the mathematical model of Lychakov et al. (2006), the value of $x$ is probably stable during a fish's lifetime.

However, the relationship between otolith mass difference and fish length is more complex. In the present work, there was no relationship between fish length and otolith mass difference. This is in agreement with the results obtained by Lychakov \& Rebane $(2004,2005)$ on several fish species. Lychakov et al. (2006) suggested three reasons for the absence of relationship; (1) it might be due to the small sample used in the study; (2) when the specimens having same range of size or do not differ markedly in size; and (3) possible inherent cause. These suggestions are evident in the data of the species in question as only 124 specimens ranging in total length between 180-220 mm were used in this work.

In conclusion, further studies with large number of specimens and wide range of body size are required to investigate; first, the relationship be- tween the otolith mass difference and the fish length; and second, to fully apprehend the specific otolith mass relations in the individual species.

No relationship is found between the magnitude of the otolith mass asymmetry and the length or mass of the fish. This finding suggests that the otolith mass asymmetry does not change with fish age. Such results could be explained on the fact that the otolith growth rate of each individual otolith has a slight variation. Thus, the direction of the otolith mass asymmetry can change in value during the fish growth period but within the range $-0.2<x<+0.2$.

The acoustic functionality of the fish can be reduced due to high otolith asymmetry but otolith mass asymmetry found in the present study is well below the critical values.

\section{References}

Jawad LA, Al-Mamry JM \& Al-Busaidi HK. 2010. Otolith mass asymmetry in the teleost Beryx splendens Lowe, 1834 (Family: Bercidae) collected from the Arabian Sea coasts of Sultanate of Oman. Thalassas, 26: 43-47.

Lychakov DV. 1992. Morphometric studies of fish otoliths in relation to vestibular function. Zh. Evoliut. Biokh. i fiziol., 28: 531-539 (in Russian).

Lychakov DV. 2002. Otolithic membrane: structural and functional organization, evolution, ecomorphological plasticity and tolerance to extreme conditions (Doctorskaya Dissertaziya), Vol 1. Sechenov Institute, St.-Petersberg (text, tables), pp. 1-266, Vol. 2 (illustrations), pp. 1-107 (in Russian).

Lychakov DV \& Rebane YT. 2004. Otolith mass asymmetry in 18 species of fish and pigeon. Journal of Gravitational Physiology, 11: 17-34.

Lychakov DV \& Rebane YT. 2005. Fish otolith mass asymmetry: morphometry and influence on acoustic functionality. Hearing Research, 201: 55-69.

Lychakov DV, Boyadhieva - Mikailov A, Christov I, Paschinin AN, Evdpkimov I. I \& Matkov AA. 1988. Changes in the otolith apparatus of rat and fish after prolonged exposure to acceleration. Kosm. Biol. Aviakosm. Medicine, 22: 27-33 (in Russian).

Lychakov DV, Rebane YT, Lombate A, Fuiman LA \& Takabayashi T. 2006. Fish Otolith asymmetry: morphometry and modelling. Hearing Research, 219: 111.

Lychakov DV, Rebane YT, Lombate A, Demestre M \& Fuiman L. 2008. Saccular otolith mass asymmetry in adult flatfishes. Journal of Fish Biology, 72: 25792594.

Scherer H, Helling K, Clarke AH \& Hausmann S. 2001. Motion sickness and otolith asymmetry. Biological Sciences of Space, 15: 401-404. 